\title{
PATH FINDER PROCESS VALIDATION OF MOIST HEAT STERILIZER IN PARENTRAL MANUFACTURING UNIT
}

\author{
Kalkotwar R.S. ${ }^{1}{ }^{1}$, Salve M.B. ${ }^{1}$, Ahire T.K. ${ }^{1}$ \\ ${ }^{1}$ Dept. of Quality Assurance, S.N.D. College of Pharmacy, Bhabhulgoan,Tal- Yeola, Dist-Nashik.(MS) India-423401 \\ Received 01 Sep 2015; Review Completed 29 Sep 2015; Accepted 07 Oct 2015, Available online 15 Nov 2015
}

\begin{abstract}
Objective: Moist heat sterilization is the most important in pharmaceutical Parentral manufacturing unit. Sterile products have several unique dosage form properties, such as freedom from microorganisms, freedom from pyrogens, freedom from particulates, and extremely high standards of purity and quality; however, the ultimate goal in the manufacture of a sterile product is absolute absence of microbial contamination. An attempt has been made in this research work to validate the Moist Heat Steriliser with technical parameters classified as Critical and Variable Parameters.

Method: Moist Heat Sterilization method is used for Sterilization of Accessories, Garments, Silicon tubes, filtration assembly etc. on basis of coagulation of cell proteins. Moist Heat Steriliser is validated every half year to ensure the system is liable to consistently, provide dehydrogenated or sterile product and meets the quality standards. Validation is done by proper planning by taking regular load and experimental load of regular batches of the product. The study is done on Heat distribution, Heat penetration, and Bio burden determination, Minimize the utility cost, and Man hours during sterilization cycle.

Result: The result found in this research work leads to setting up new approach to Validate Moist Heat Steriliser in Parentral manufacturing unit with cost effective way.

Conclusion: The Path finder validation process setup through this project is Cost saving through Energy as well as Man Hour Saving and Breakage of Units also maintain Sterility in product. It is helpful to find out Hot and Cold Spots in Moist Heat sterilizer and Designing and Placement of RTDs. The findings were submitted to the Parentral Department of Vital HealthCare Pvt. Ltd., Satpur. MIDC, Nashik.

Keywords: Moist heat Sterilization, Process Validation, Critical and Variable parameters.
\end{abstract}

\section{INTRODUCTION:-}

Validation manufacturing processes has always been important in pharmaceutical quality Assurance, recent emphasis on their documentation by the FDA has resulted in a more careful look at the implementation of validation procedures. The process validation Define as "a documented program which provides a high degree of assurance that a specific process will consistently produce a product meeting its predetermined specification and quality attributes". ${ }^{1}$ The principles of qualification and validation which are applicable to the manufacture of medicinal products. It is a requirement of GMP that manufacturers identify what validation work is needed to prove control of the critical aspects of their particular operations. ${ }^{2}$

The Aim of a sterilization process is to destroy or eliminate microorganism which are present on or in an object or preparation, to make sure that this has been achieved with an extremely high level of probability and to assure that the object or preparation is free from infection hazard. "Sterilization is a term referring to any process that eliminates or kills all forms of microbial life, including transmissible agents such as fungi, bacteria , viruses , spore forms, etc. present on a surface, contained in a fluid, in medication, or in a compound such as biological culture media".

\section{A. Types of Validation: ${ }^{3}$}

Validations are of following types-

1. Prospective Validation

2. Concurrent Validation

3. Retrospective Validation

4. Revalidation

*Corresponding Author:

Dr. Ramesh Kalkotwar, Associate Prof and HOD QAT SND College of Pharmacy, Yeola, Dist. Nashik 423401 E mail: rameshkalkotwar@gmail.com 


\section{B. Methods of Sterilization:-}

Sterilisation methods are as follows-

\section{Physical}

2. Chemical

3. Mechanical (Filtration)

\section{AIM AND OBJECTIVE:}

The main objective of this project is to validate the Moist Heat sterilizer in Parenteral manufacturing unit of Vital Healthcare, MIDC, Satpur, Nashik and suggest cost Effective sterilization process. Study of use Experimental work Sterilization cycles for Accessories and Terminal sterilization according to review study. And also check the critical as well as variable study.

\section{A. Sterilization:}

Table 1: Sterilization cycle

\begin{tabular}{|l|l|l|l|}
\hline $\begin{array}{l}\text { Sr. } \\
\text { no. }\end{array}$ & Loads & $\begin{array}{l}\text { As per SOP of } \\
\text { Vital Healthcare } \\
\text { Pvt. Ltd. }\end{array}$ & Experimental \\
\hline 1 & $\begin{array}{l}\text { Access- } \\
\text { ories }\end{array}$ & $\begin{array}{l}\text { Accessories load } \\
121^{0} \mathrm{C} \text { for } 60 \mathrm{~min} .\end{array}$ & $\begin{array}{l}\text { Accessories load } \\
121^{0} \mathrm{C} \text { for } 30 \mathrm{~min} .\end{array}$ \\
\hline 2 & $\begin{array}{l}\text { Termi- } \\
\text { nal }\end{array}$ & $\begin{array}{l}\text { Terminal load } \\
121^{0} \mathrm{C} \text { for } 30 \mathrm{~min} .\end{array}$ & $\begin{array}{l}\text { Terminal load } \\
121^{0} \mathrm{C} \text { for } 30 \mathrm{~min} .\end{array}$ \\
\hline
\end{tabular}

Experimental work gives following advantages:-

1. Improve sterilization.

2. Reduces the visual rejection because of visual particle.

3. Less Consumption of electricity.

4. Time saving process.

5. Easy for operation.

6. Reduce Man Hours.

B. Cycles used in moist heat sterilization: ${ }^{4-6}$

For moist heat sterilization, the accepted range of sterilizing temperatures is $118^{\circ}$ to $134^{\circ} \mathrm{C}$. The US Pharmacopeia (USP) explains in a footnote that "An autoclave cycle, where specified in the compendia for media or reagents, is a period of $15 \mathrm{~min}$ at $121^{\circ} \mathrm{C}$, unless otherwise indicated". The European Pharmacopoeia (EP) and the British Pharmacopoeia (BP) recommend a heating process at a minimum of $121{ }^{\circ} \mathrm{C}$ for $15 \mathrm{~min}$ as a reference condition for aqueous preparations. The text of both books states that other conditions of time and temperature may be used provided that the process chosen has been satisfactorily demonstrated to deliver an adequate and reproducible level of lethality when operating routinely within the established tolerances.

\section{MATERIAL AND EQUIPMENT:}

\section{A) Material:}

1. Physical Indicator (Thermo Graph and Print out of Microprocessor)

2. Chemical indicator (steam- clox and Bowie Dick Test Paper)
3. Biological indicator (Geobacillus Stero-thermophilis)

4. 16 RTD Flexible Probes (Sensitivity 0.1 degree)

5. 8 Fixed RTD Probes (Sensitivity 0.1 degree)

6. Ice Pack (For Calibration of RTD Sensor)

7. Lighter (For Calibration of RTD Sensor)

8. Accessories (Syringes, Hand gloves, Filling Garment, Silicon Tubing)

\section{B) Equipment:}

1. Autoclave to be validated (Model- ID-W-195,MakeChandrashekhar Enterprises, Ahmadabad)

2. Multichannel Data Logger (The data logger must have a real time clock to record temperature at predetermined time gap.)

3. Std. Thermometer

4. Incubator

C. Indicators: ${ }^{7}$

\section{Physical Indicator: ${ }^{8}$}

Pressure and temperature recording devices. Thermocouples can be placed inside the load to determine the temperature achieved in the load itself.

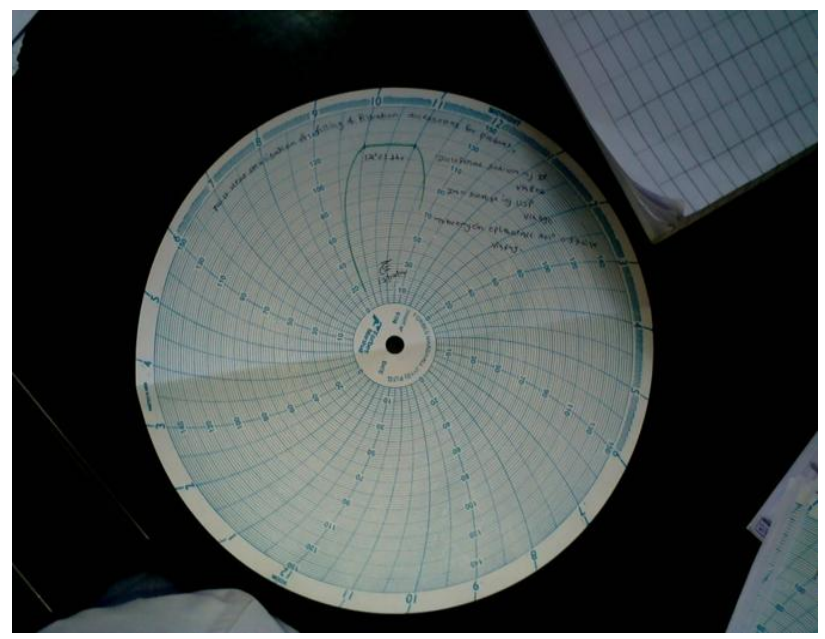

Figure 1: Thermo Radix Graph

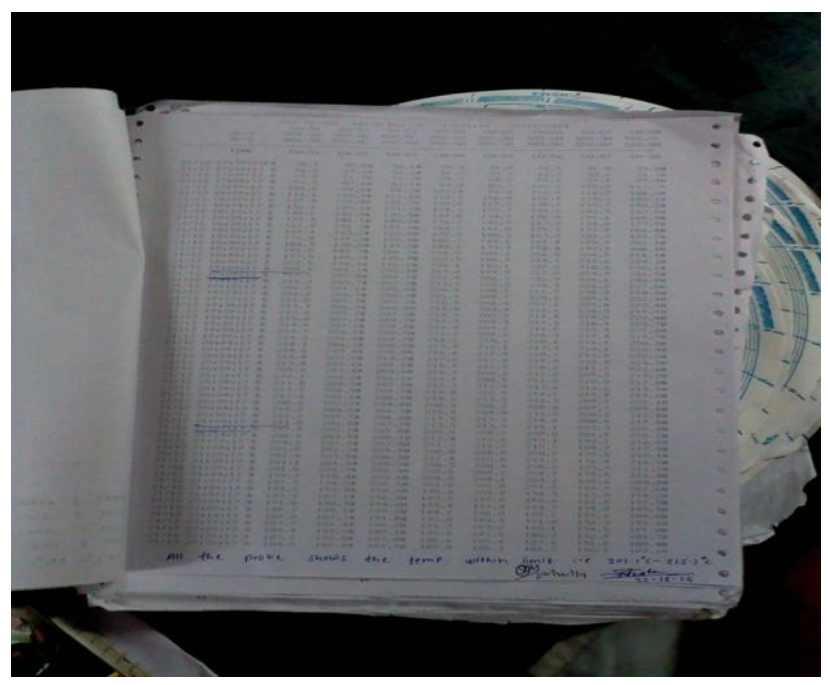

Figure 2: Printout of Microprocessor 


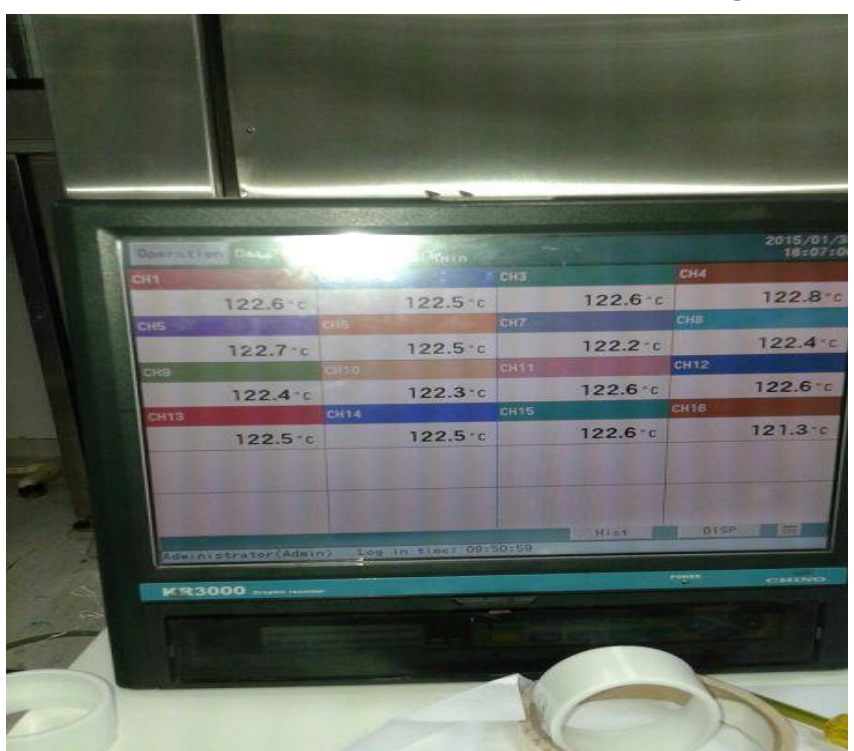

Figure 3: Digital temperature readout.

\section{Chemical Indicator: ${ }^{8}$}

These indicators change colour after being exposed to specific temperatures. There are two types of chemical indicators, temperature sensitive tape (autoclave tape) and integrated chemical indicator strips. For autoclave tape, the colour change will occur upon exposure to the given temperature; it is not time related.

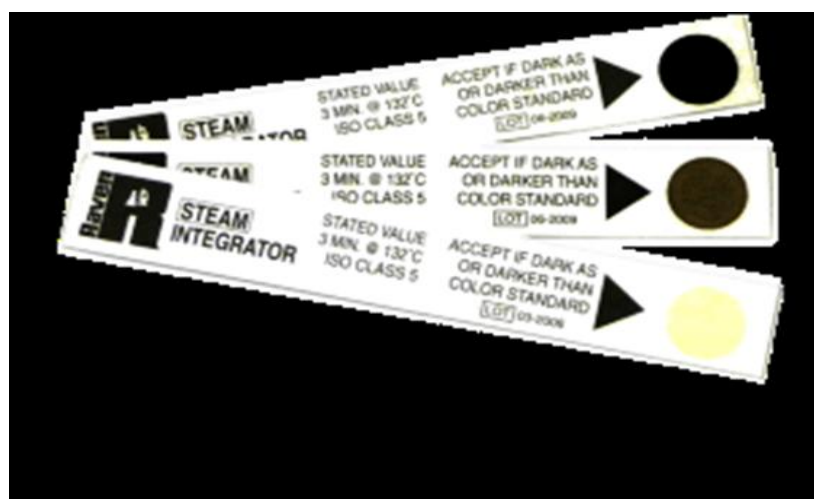

Figure 4: Steam- Integrator

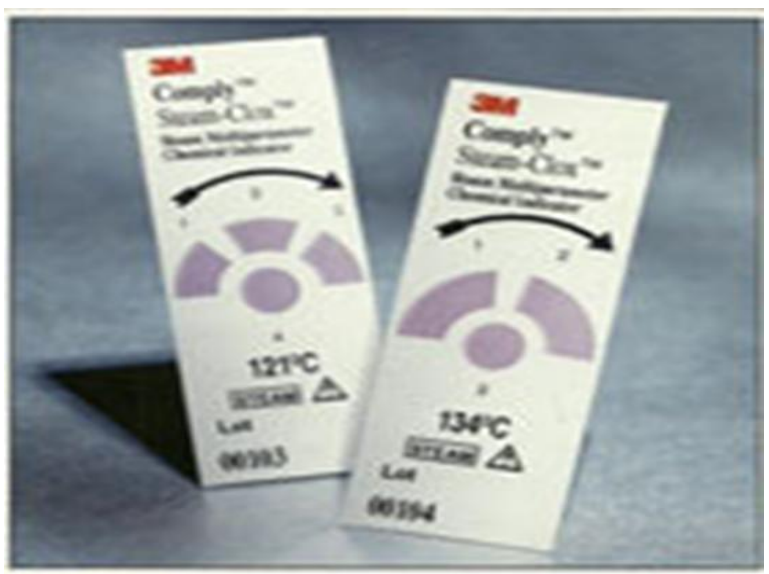

Figure 5: Steam- Clox

\section{Biological Indicator:}

Biological indicators are used in the efficacy testing of the autoclave process to effectively sterilize the contents being treated. G. stearothermophilus spores are used, as they are the most resistant organism to steam autoclaving. To determine the effectiveness of the autoclave process the biological indicator must be placed in a typical test load (solid or liquid) and exposed to the typical cycle conditions.

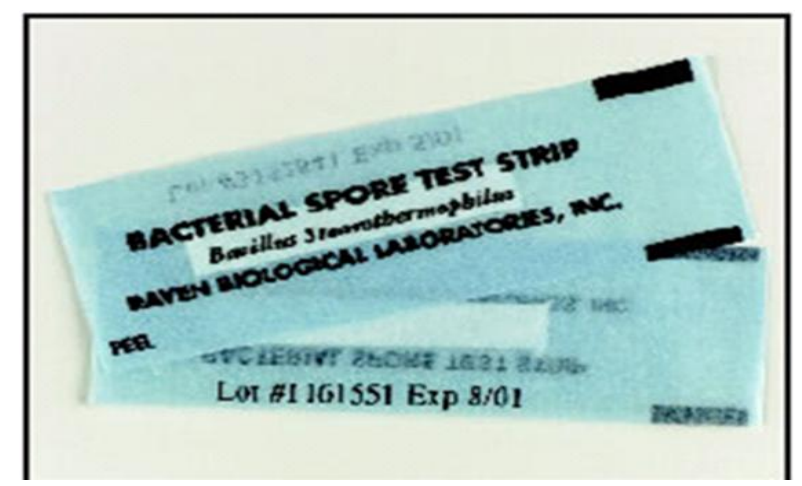

Figure 6: Bacterial Spore Test Strip
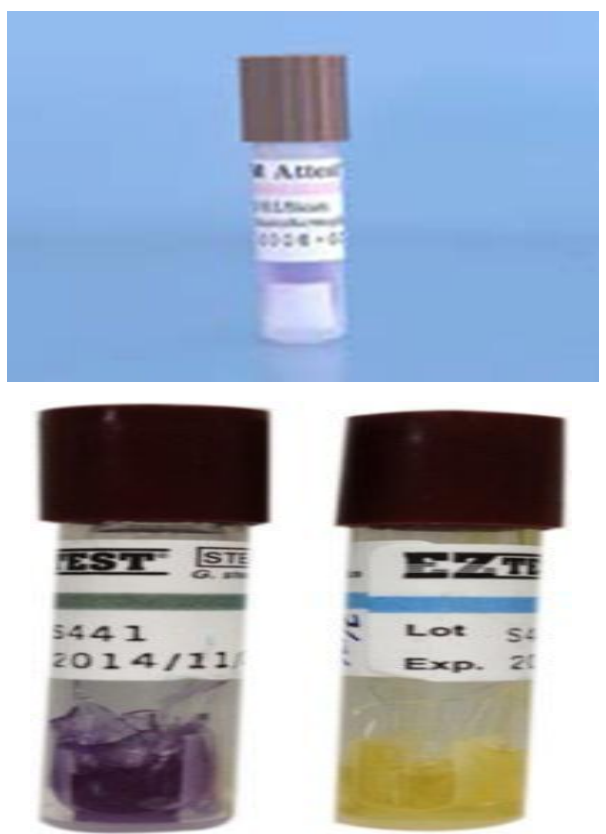

Figure 7: Biological Indicator

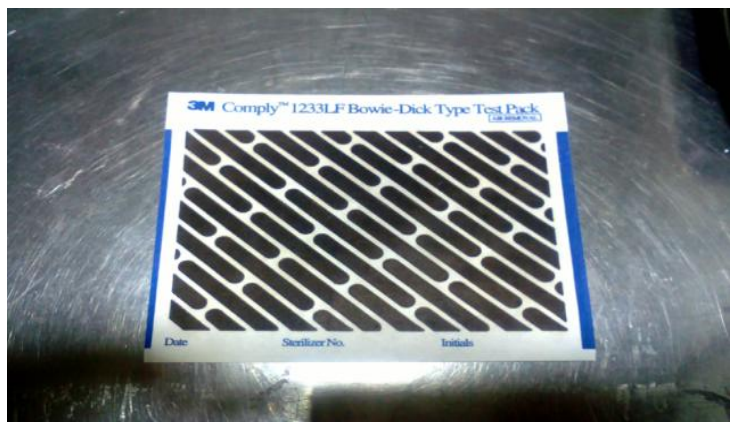

Figure 8: Bowie Dick Type Test Pack.

C. Validation Testing: ${ }^{8}$

Validation must be done in two parts.

A) Empty chamber testing (Heat distribution study)

B) Loaded chamber testing (Heat distribution study $\&$ Heat penetration study)

A. Empty Chamber Testing:

A.1. Heat distribution in an empty chamber. 
A.2. During installation, the Heat distribution study is done 3 times. For revalidation it may be done once. ${ }^{16}$ RTDs must be placed at different locations of chamber.

A.3.The RTDs must be at least $100 \mathrm{~mm}$ away from the side walls of chamber.

A.4.One RTD placed at the drain point.

A.5. No RTDs must touch any metal surface or the wall of the chamber.

A.6. Run cycle at normal parameters $121^{0} \mathrm{C} / 15 \mathrm{PSI} / 20$ minutes and temperature from all probes is recorded with a time interval of every one minute.

A.7. Three such cycles are run and the cold point is determined. For revalidation only one cycle is sufficient.

\section{B. Loaded Chamber Testing:}

Loaded chamber testing must be done in two parts:

\section{B. 1. Heat distribution study}

\section{B. 2. Heat penetration study}

\section{B.1. Heat distribution study:}

B.1.1. Three cycles of each testing must be taken. (For revalidation only one cycle is taken).

B.1.2.The RTDs must be at least $100 \mathrm{~mm}$ away from the side walls of chamber.

\section{B.1.3.One RTD placed at the drain point.}

B.1.4. No RTDs must touch any metal surface or the wall of the chamber.

B.1.5. Half of the temperature probes sensing RTDs must be near the vessels, bungs,

Filtration tubing's, Filling accessories etc and rest are suspended at different locations in autoclave.

B.1.6. Run cycle at normal parameters $121^{0} \mathrm{C} / 15$ $\mathrm{PSI} / 20$ minutes and temperature from all probes is recorded with a time interval of every one minute.

B.1.7. Loading configuration must be drawn showing RTDs position.

B.1.8. Cold spot and HOT spot is recorded and marked in loading diagram.

\section{B.2. Heat penetration study:}

B.2.1Three cycles must be run with different loads spiked with biological \& chemical indicators..The RTDs must be at least $100 \mathrm{~mm}$ away from the side walls of chamber.

B.2.2.One RTD placed at the drain point.

B.2.3. No RTDs must touch any metal surface or the wall of the chamber.

B.2.4. Half of the temperature probes sensing RTDs must be near the vessels, bungs, Filtration tubing's, Filling accessories etc and rest are suspended at different locations In autoclave. At least five Biological indicators must be placed in each cycle.

(Spore population of Biological indicators must not be less than $10^{6}$ per ampoule.)
B.2.5. At least Ten Chemical indicators must be placed in each cycle.

B.2.6. Run cycle at normal parameters $121^{\circ} \mathrm{C} / 15$ $\mathrm{PSI} / 20$ minutes and temperature from all probes is recorded with a time interval of every one minute. Loading configuration must be drawn showing RTDs position.

\section{Acceptance Criteria:}

1. All the probes must show temperature not less than $121^{\circ} \mathrm{C}( \pm)$ during the sterilization cycle.

2. The temperature difference between 2 probes must not be more than $2^{0} \mathrm{C}$.

3. After completion of sterilization cycle, biological indicator ampoules must be incubated and it must not show any growth at the end of incubation time.

\section{Heat-Distribution Studies: ${ }^{9}$}

Heat-distribution studies include two phases:

(1) Heat distribution in an empty autoclave chamber and,

(2) Heat distribution in a loaded autoclave chamber.

Between 10 and 20 thermocouples should be used per cycle. Thermocouples should be secured inside the chamber according to a definite arrangement Teflon tape can be used to secure thermocouples. The trips where the wires are soldered should not make contact with the autoclave interior walls or any metal surface. One thermocouple each should remain in an ice bath and high-temperature oil bath during each cycle for reference when the temperature monitoring equipment has the capability for electronically compensating each temperature measurement against an internal reference. Heat-distribution studies following the initial study may employ fewer thermocouples as the cool spot in the chamber and in the load is identified. The key is to identify on a reproducible basis the location of the cool spot and the effect of the load size and/or configuration on the cool spot location. Most experts suggest the study of the minimum and maximum load size in the proper configuration in elucidating where the cool spot is located.

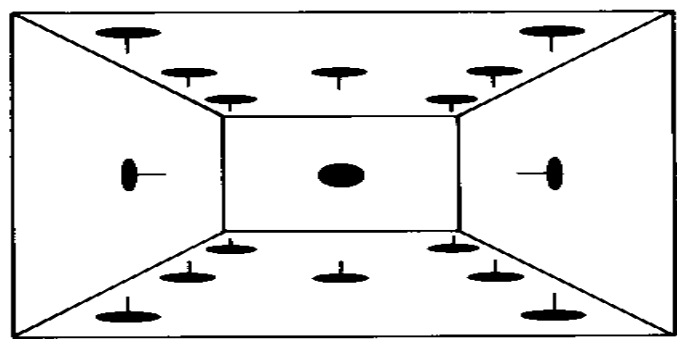

Figure 9: Suggested locations for thermocouples on a single shelf for heat-distribution studies in heat sterilizers

\section{Empty Chamber Temperature Distribution: ${ }^{10}$}

This study has traditionally been considered a critical aspect of sterilizer qualification. The intent of this study is to demonstrate the temperature uniformity and stability of the sterilizing medium throughout the 
sterilizer. Temperature distribution studies should initially be conducted on the empty camber. Temperature uniformity may be influenced by the type, size, design, and installation of the sterilizer. A satisfactory empty chamber temperature uniformity should be established by the User Requirements. A narrow range is required and is generally acceptable if the variation is less than $\pm 1^{0} \mathrm{C}\left( \pm 2^{0} \mathrm{~F}\right)$ the mean chamber temperature.

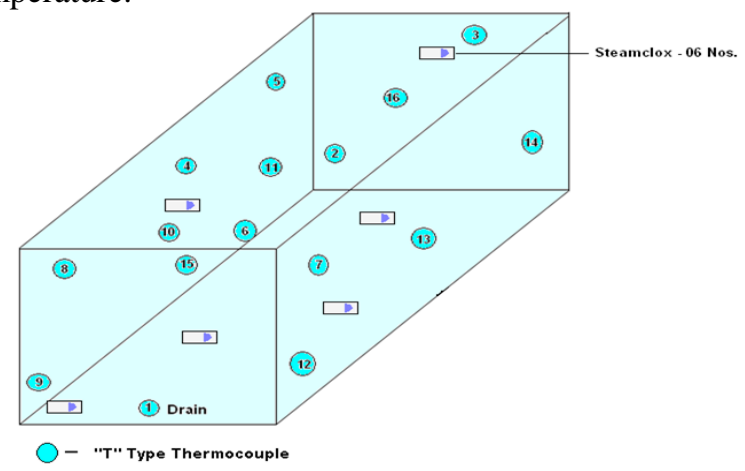

Figure 10: Sensor Location for Empty Cycle at 121 ${ }^{\circ} \mathrm{C}$ for 20 minutes

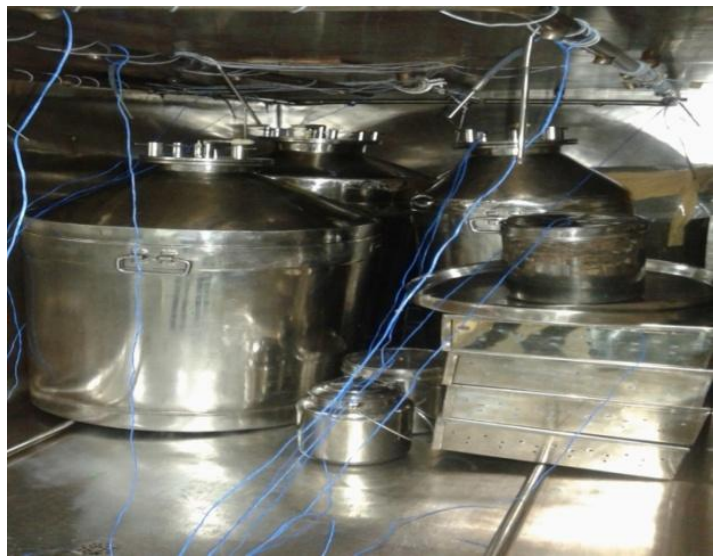

Figure 11: Loaded Autoclave Chamber

2. Heat-Penetration Studies:

This is the most critical component of the entire validation process.

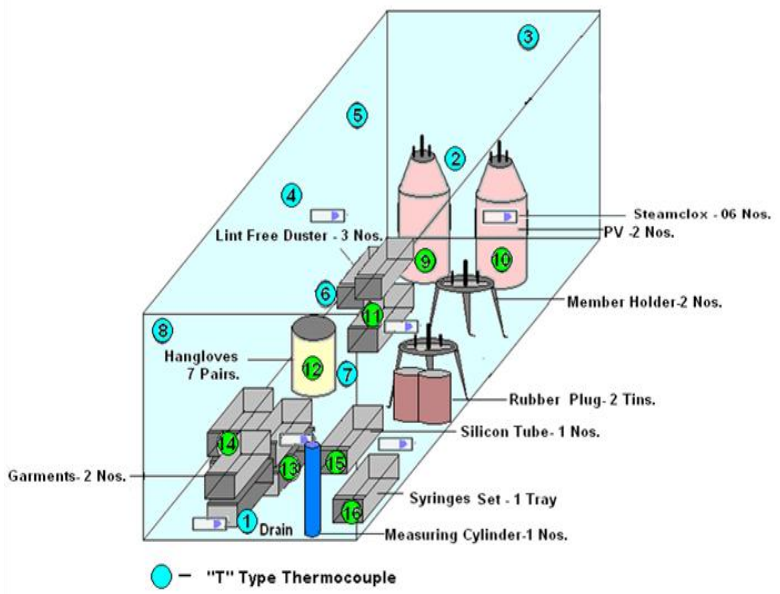

Figure 12: Sensor Location for Minimum Load Cycle at $121{ }^{\circ} \mathrm{C}$ for 30 minutes

Heat penetration studies comprise the core of sterilization process confirmation. The intent of these studies is to confirm that the slowest to heat objects within a specified load has achieved the requisite lethality. Cold spots originate because of the varied rate of heat transfer throughout the load.

Lethal rates can be determined from the temperature data obtained from the heat penetration studies. The temperature data are converted by the following formula:

$$
L=\log -1 \frac{T o-T b}{Z}=10 \frac{T o-T b}{Z}
$$

Where,

$\mathrm{L}$ is the instantaneous lethality,

$\mathrm{T}_{0}$ is the temperature within the object or container,

$\mathrm{Tb}$ is the process temperature $\left(121^{\circ} \mathrm{C}\right)$ and

$\mathrm{Z}$ is the temperature required to change the $\mathrm{D}$-value by a factor of 10 . (For this calculation $\mathrm{Z}$ is set to 10 , based on the experimental values for highly resistant organisms.)

The total lethality of the cycle is then determined byintegrating over time as follows:

$\mathbf{F o}=\sum 10^{(\mathrm{T}-121) / 10}{ }_{\Delta \mathbf{t}}$

Where $\Delta \mathrm{t}$ is the chosen time interval and,

$\mathrm{T}$ is the average temperature over that interval.

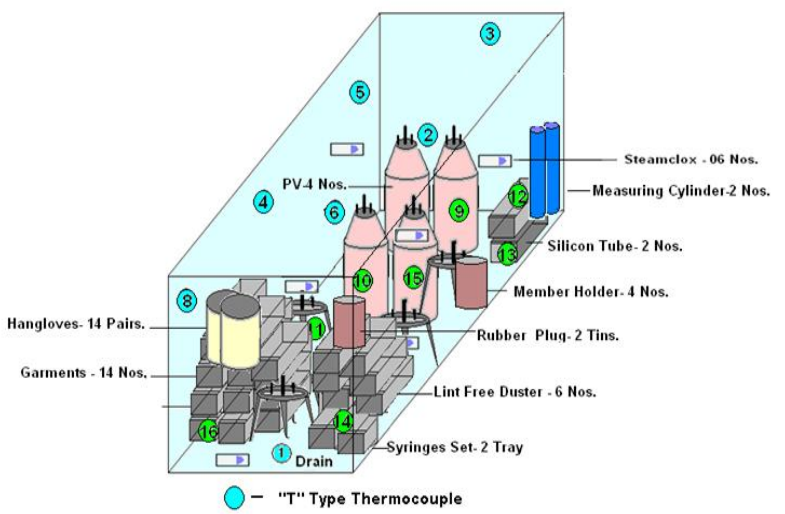

Figure 13: Sensor Location for Maximum Load Cycle at $121{ }^{\circ} \mathrm{C}$ for 30 minutes

\section{AIR REMOVAL TEST: ${ }^{11}$}

The ability of the pre-vacuum autoclaves to effectively remove the air and non-condensable gases should be tested. If the air is not effectively removed, air pockets will occur in the chamber and sterilization conditions will not be attained.

Bowie-Dick or DART Test pack, the uniformity of the colour change on the indicator sheet should be checked. $\left(3.5\right.$ min. at $\left.134{ }^{\circ} \mathrm{C}\right)$

The presence of air prevents proper penetration of the load by steam and thus inhibits sterilization. 


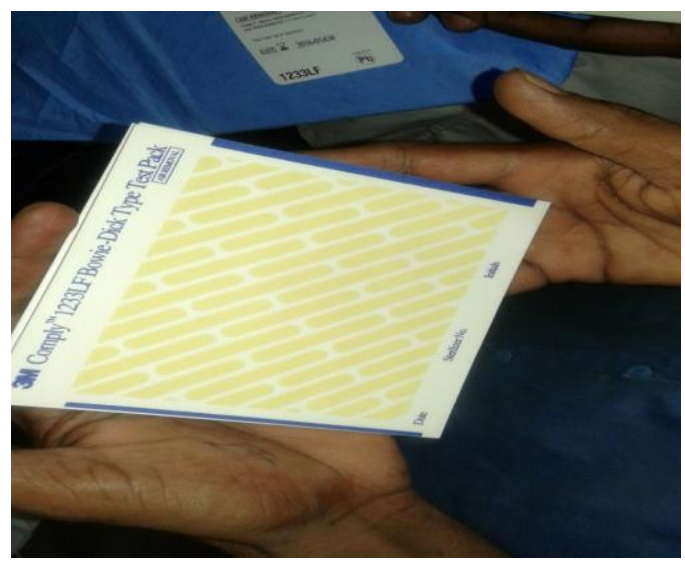

Figure 14: Bowie Dick test paper (Before sterilization)

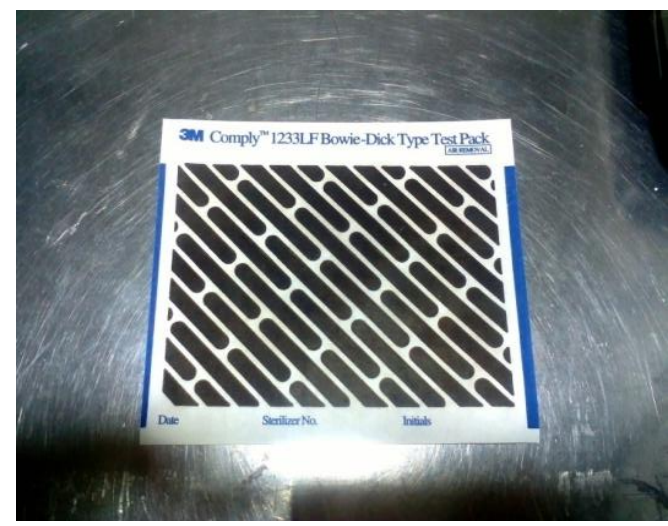

Figure 15: Bowie Dick test paper (After sterilization)

\section{F value $^{12}$}

Equivalent time at a specific temperature delivered to a container or unit of product.

\section{D value. ${ }^{12}$}

Time in minutes required to inactivate $1 \log$ of a challenge microorganism.

\section{F VALUE}

The $\mathrm{F}$ value is used as a measurement of sterilization effectiveness. $\mathrm{F}(\mathrm{T}, \mathrm{z})$ is defined as the equivalent time at temperature $\mathrm{T}$ delivered to a container or unit of product for the purpose of sterilization, calculated using a specific value of $\mathrm{z}$. The term F0 is defined as the number of equivalent minutes of steam sterilization at temperature $121.1^{\circ} \mathrm{C}$ delivered to a container or unit of product calculated using a $\mathrm{z}$ value of $10^{\circ} \mathrm{C}$.

\section{Mathematical $\mathbf{F}_{\mathbf{0}}$}

Fo is calculated using the following equation:

$F_{0}=\Delta \mathrm{t} \Sigma 10^{(\mathrm{T}-121 / \mathrm{Z})}$

where:

" $\Delta \mathrm{t}$ " is the time interval between measurements of temperature $(\mathrm{T})$.

" $\mathrm{T}$ " is the temperature of sterilized product at time (t)
" $Z$ " is a temperature coefficient which measures the number of degrees required to change the D-value of an organism by $1 \log$.

" 10 " is the microbial death constant.

$\mathrm{F}_{0}=\mathrm{D}_{121}(\log \mathrm{A}-\log \mathrm{B})$

where:

" $\mathrm{D}_{121}$ " is equal to the time at $121^{\circ} \mathrm{C}$ to reduce the population of the most resistant organism in each product container by $90 \%$ (or $1 \log$ )

" $\mathrm{A}$ " is the number of micro-oganisms per container.

" $\mathrm{B}$ " is the maximum acceptable probability of survival

(Sterility Assurance Level, $10^{-6}$ ).

\section{7 . D VALUE}

The $\mathrm{D}$ value is a term used to describe the relative resistance of a particular microorganism to a sterilization process. DT (or $\mathrm{D}(\mathrm{T})$ ) is defined as the time required at temperature $\mathrm{T}$ to reduce a specific microbial population by $90 \%$, or, as the time required for the number of survivors to be reduced by a factor of 10 . The letter "D"stands for the fact that D value is also referred to as the decimal reduction time, the word decimal being defined by most dictionaries as "pertaining to or founded on the number 10."

\section{Z VALUE ${ }^{13}$}

These terms heretofore have been applied exclusively in the validation of heat sterilization processes. The $\mathrm{Z}$ value is the reciprocal of the slope resulting from the plot of the logarithm of the $D$ value versus the temperature at which the $\mathrm{D}$ value was obtained. The $\mathrm{Z}$ value may be simplified as the temperature required for a one-log reduction in the $\mathrm{D}$ value:

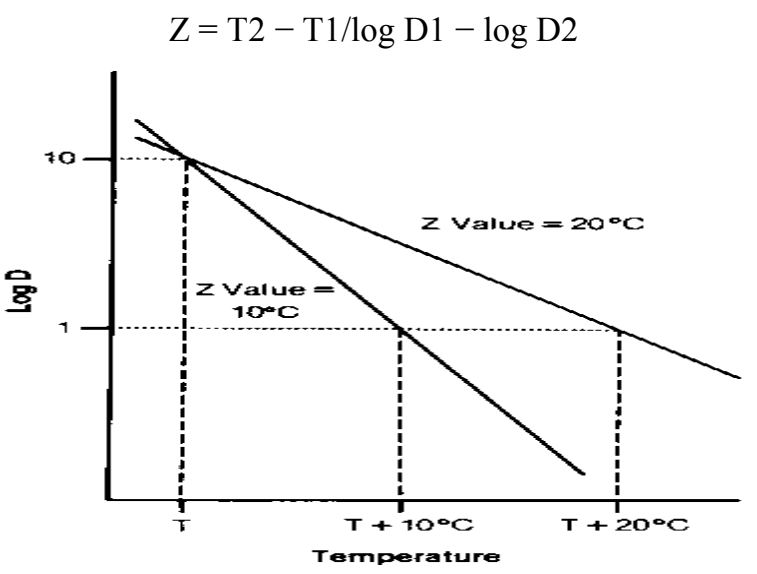

Figure 16: Thermal resistance plots of $\log D$ versus temperature, showing slopes equivalentto $\mathrm{Z}=10^{\circ} \mathrm{C}$ and $\mathrm{Z}=20^{\circ} \mathrm{C}$.

$\mathrm{F}=\Delta \mathrm{t} \Sigma 10^{(\mathrm{T}-\mathrm{T} 0) / \mathrm{Z}}$

Where,

' $\Delta \mathrm{t}$ ' is the time interval for the measurement of product temperature $\mathrm{T}$. and

' $\mathrm{T}_{0}$ ' is the reference temperature (e.g., $\mathrm{T} 0=121^{\circ} \mathrm{C}$ for steam sterilization). 


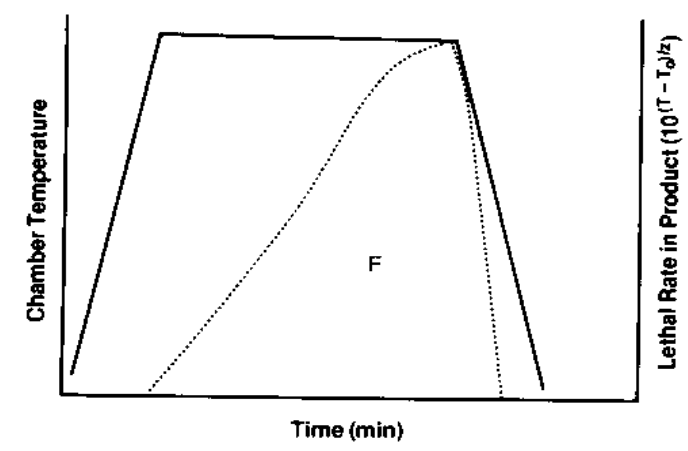

Figure 17: Plot showing the difference between chamber temperature versus time and, lethal rate in the product versus time. $F$ is the area under the dotted line curve.

\section{RESULT AND DISCUSSION:}

1. The result observed in the sterilization of batches of Metoclopramide Injection IP $5 \mathrm{mg} / \mathrm{ml} 2 \mathrm{ml}$, Batch no. V14895 B. Size: - 200 lit prior to process validation set in the project are annexed herewith as per QCM/007/F $1-01$.

2.

Table 2: Result

\begin{tabular}{|c|l|c|c|}
\hline Batch & $\begin{array}{c}\text { Sterilization conditions } \\
\text { (Temp/time/pressure) }\end{array}$ & Sterility & $\begin{array}{c}\text { Optical/ visual } \\
\text { inspection report }\end{array}$ \\
\hline $\begin{array}{c}\text { Metoclopramide Injection IP 5mg/ml 2ml } \\
\text { Batch no. V14895 B. Size:- 200 lit }\end{array}$ & $\begin{array}{l}\text { Accessories load } \\
121^{0} \mathrm{C} \text { for 30 min. }\end{array}$ & Pass & NA \\
\hline $\begin{array}{c}\text { Metoclopramide Injection IP 5mg/ml 2ml } \\
\text { Batch no. V14895 B. Size:- 200 lit }\end{array}$ & $\begin{array}{l}\text { Terminal load } \\
121^{0} \mathrm{C} \text { for 30 min. }\end{array}$ & Pass & $\begin{array}{c}1.1 \% \\
\text { Limit : Below 3\% }\end{array}$ \\
\hline
\end{tabular}

\section{Critical parameters:}

Table 3: Critical parameters (After Proposed Process Validation of AUTOCLAVE W-195, the results found to be as under.)

\begin{tabular}{|c|c|c|}
\hline Param-eter & Load taken & Load Use to take \\
\hline $\begin{array}{l}\text { Critical Parameters } \\
\text { considered }\end{array}$ & $\begin{array}{l}\text { Batch-A Metoclopramide Injection IP 5mg/ml } \\
\text { 2ml, Batch no. V14895 B. Size:- } 200 \text { lit }\end{array}$ & $\begin{array}{c}\text { Batch -B Metoclopramide Injection IP } \\
5 \mathrm{mg} / \mathrm{ml} 2 \mathrm{ml} \text {, Batch no. V14751 B. Size: } \\
100 \text { lit }\end{array}$ \\
\hline 1.Sterilization & $\begin{array}{l}\text { 1. Accessories load } 121^{0} \mathrm{C} \text { for } 30 \mathrm{~min} . \\
\text { 2.Terminal load } 121^{\circ} \mathrm{C} \text { for } 30 \mathrm{~min} \text {. }\end{array}$ & $\begin{array}{l}\text { 1. Accessories load } 121^{\circ} \mathrm{C} \text { for } 30 \mathrm{~min} \text {. } \\
\text { 2.Terminal load } 121^{\circ} \mathrm{C} \text { for } 30 \mathrm{~min} \text {. }\end{array}$ \\
\hline 2.Less Rejection & Visual rejection for this batch is $1.09 \%$. & Visual rejection for this batch is $2.3 \%$. \\
\hline 3.Energy Saving & $\begin{array}{l}\text { We reduce our cycle time from } 60 \mathrm{~min} \text { to } 30 \\
\text { min, for accessories sterilization. And for } \\
\text { terminal sterilization we kept cycle time as it is. } \\
\text { it means we reduces } 30 \mathrm{~min} \text { in accessories } \\
\text { sterilization load. If, } 600 \mathrm{~kg} \text { pure steam } / 60 \mathrm{~min} \\
\text { then, } 300 \mathrm{~kg} \text { pure steam } / 30 \mathrm{~min} \text {. According to } \\
\text { that we saved energy up to } 300 \mathrm{~kg} \text { pure steam. }\end{array}$ & $\begin{array}{l}\text { As per previous cycle, we took } \\
\text { accessories load on } 121{ }^{\circ} \mathrm{C} \text { for } 60 \mathrm{~min} \text {. } \\
\text { and Terminal load on } 121^{\circ} \mathrm{C} \text { for } 30 \mathrm{~min} \text {. } \\
\text { No energy saving. }\end{array}$ \\
\hline 4.Man Hours Save & $\begin{array}{l}\text { After experimental work we observed that, one } \\
\text { cycle of } 2 \text { hours for accessories and } 1 \text { hour for } \\
\text { terminal sterilization. } \\
\text { For accessories sterilization } \\
2 \mathrm{hr} \times 2 \text { person }=4 \text { hours. } \\
\text { Save } 30 \text { min. } \\
\text { for terminal sterilization } \\
1 \mathrm{hr} \times 2 \text { person }=2 \text { hours }\end{array}$ & $\begin{array}{l}\text { For } 1 \text { load of autoclave we require } 2 \\
\text { people and } 2 \text { hrs. } 30 \text { min to complete } \\
\text { load from loading to unloading of } \\
\text { amp/vial. As per regular cycle. } \\
\text { For accessories sterilization: } \\
2 \mathrm{hr} 30 \text { min } x 2 \text { person }=5 \text { hours } \\
\text { (For terminal sterilization: } \\
1 \text { hr } x 2 \text { person }=2 \text { hours } \\
\text { No man hour saving. }\end{array}$ \\
\hline $\begin{array}{l}\text { 5.Breakage during } \\
\text { sterilization }\end{array}$ & $\begin{array}{l}\text { Breakage During Terminal sterilization is } 63 \\
\text { Amp. }\end{array}$ & $\begin{array}{l}\text { Breakage During Terminal sterilization is } \\
89 \text { Amp. }\end{array}$ \\
\hline
\end{tabular}


2 Variable parameter:

Table No.4:- Variable parameter

\begin{tabular}{|l|c|c|}
\hline $\begin{array}{l}\text { Variable Parameters } \\
\text { considered }\end{array}$ & $\begin{array}{c}\text { Batch-A-Metoclopramide Injection IP } \\
5 \mathrm{mg} / \mathrm{ml} 2 \mathrm{ml} \text {, Batch no. V14895 B. Size:- } \\
200 \mathrm{lit}\end{array}$ & $\begin{array}{c}\text { Batch -B- Metoclopramide Injection IP } \\
5 \mathrm{mg} / \mathrm{ml} \mathrm{2ml,} \mathrm{Batch} \mathrm{no.} \mathrm{V14751} \mathrm{B.} \mathrm{Size:} \mathrm{-} \\
100 \text { lit }\end{array}$ \\
\hline $\begin{array}{l}\text { 1.Temperture and } \\
\text { time }\end{array}$ & $\begin{array}{l}\text { 1. Accessories load } 121^{\circ} \mathrm{C} \text { for } 30 \mathrm{~min} . \\
2 . \text { Terminal load } 121^{\circ} \mathrm{C} \text { for } 30 \mathrm{~min} .\end{array}$ & $\begin{array}{l}\text { 1. Accessories load } 121^{0} \mathrm{C} \text { for } 30 \mathrm{~min} . \\
\text { 2.Terminal load } 121^{0} \mathrm{C} \text { for } 30 \mathrm{~min} .\end{array}$ \\
\hline
\end{tabular}

\begin{tabular}{|l|l|l|}
\hline 2. Cold Spot & $\begin{array}{l}\text { During the cycle of load, we found that 8 } \\
\text { no. probe is cold spot near to the autoclave } \\
\text { unloading side door. }\end{array}$ & $\begin{array}{l}\text { During the cycle of load, we found that 3 no. } \\
\text { probe is cold spot near to the autoclave } \\
\text { unloading side door. }\end{array}$ \\
\hline 3.Hot Spot & $\begin{array}{l}\text { During the cycle of load, we found that 1 } \\
\text { no. probe is hot spot near to the drain of } \\
\text { autoclave. }\end{array}$ & $\begin{array}{l}\text { During the cycle of load, we found that 5 no. } \\
\text { probe is hot spot near to the chamber steam } \\
\text { opening. }\end{array}$ \\
\hline $\begin{array}{l}\text { 4.Design of probe } \\
\text { placement }\end{array}$ & $\begin{array}{l}\text { We suggest that the equal Probe } \\
\text { distribution. We add 2 more probe. }\end{array}$ & $\begin{array}{l}\text { In this load 8 NOS of probe and 1 is for } \\
\text { graph, and 1 is for radix. }\end{array}$ \\
\hline
\end{tabular}

\section{Cost saving:-}

According to commercial rate of diesel is $60 \mathrm{Rs} / \mathrm{liter}$.

Autoclave produces $600 \mathrm{~kg}$ pure steam/ hour.

In 1 minute autoclave consume around $800 \mathrm{ml}$ diesel.

Table 5: Cost saving

\begin{tabular}{|c|c|}
\hline Vital & Experiment \\
\hline $\begin{array}{c}\text { For load of 1hours we } \\
\text { spent 2880 Rs. }\end{array}$ & For load 30 min we spent \\
1440 Rs.
\end{tabular}

As per our experimental work, we save 1440 Rs. / cycle.

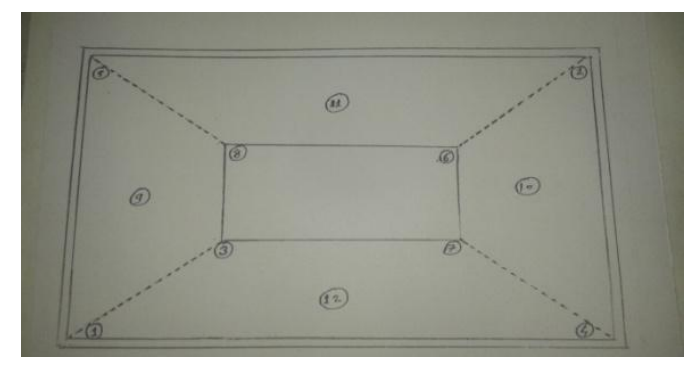

Figure 19: Design of probe placement, as per experimental work.

\section{CONCLUSION:}

This project work was carried out to Validate the Moist Heat sterilizer in Parentral Manufacturing Unit. The results found to be good and within targeted limits. It is saving Cost through Energy Saving, Man Hour Saving and Breakage of Units. We have also tried to find out Hot and Cold Spots in Moist Heat sterilizer and Design Placement of RTDs for Moist Heat sterilizer of the Parentral Manufacturing Unit and suggested all the parameters and findings with the Parentral Department of Vital HealthCare Pvt. Ltd., Satpur. MIDC, Nashik.

\section{CONFLICT OF INTERESTS:}

Authors declared there is no conflict of interest.

\section{REFERENCES:}

1. Boca BM , Pretorius E, Gochin R, Chapoullie R, And Apostolidess Z, An Overview Of The Validation Approach For Moist Heat Sterilization Part-I , Review Article In Pharmaceutical Technology Sept- 2002:10-20

2. Raymond G, Lewis P E, "Practical Guide To Autoclave Validation", Review Article In Pharmaceutical Engineering, July/August-2002:1-8

3. Venkateswarwa Reddy B, Reddy BR, A Review on Qualification of Autoclave, RMG, FBD, Cone blender ,tablet compression machine, journal of globle trends in pharmaceutical sciences Jan- march 2014: 1- 8.

4. Indian pharmacopoeia Volume I, sterilization, the Indian Pharmacopoeia Commission Ghaziabad 2014: 565-567.

5. British Pharmacopoeia united state pharmacopeia convection, twentieth Washington D.C 2014(II): 241.

6. USPXX the United State Pharmacopeia, NFXV the National Formulary2014: 1037- 1040.

7. Hugo and Russell's Pharmaceutical Microbiology edited by Stephan P. Denyer, Norman A. Hodges and Sean P. Gorman, Blackwell publishing 1977, Chapter Sterilization procedure and sterility Assurance seventh edition 2005 355- 346

8. Bhana Nikhilesh et al ,ZanwarAartiSachin, Trivedi Vishal, Jain Dipesh A Review On "Steam Sterilization A Method Of Sterilization" Journal Of Biological And Scintific Opinion, 2013 (1):2-4

9. SOP of Vital Healthcare Pvt. Ltd, SOP on autoclave validation, SOP No. QA/042-00.

10. Robert A Nash, And Alfred H Walhter," Pharmaceutical Process Validation An International" ,Third Edition , Revised And Expanded Volume -I: 95-102.

11. Fredrick J. Carleton, James P Agalloco, " Validation Of Pharmaceutical Processes , Sterile Product" SecondEdition, Chapter no-14, Edited By Phil Desantis, Fluor Daniel Inc.Marlton, New Jersey: 413-449.

12. Suat Kumser, Validation Of Sterilization Equipment, Aseptic Area Validations, Turkish Pharmaceutical And Chemical Industry Research And Devlopment Foundation. Istanbul Hilton, May,2002: 2-3.

13. Dr. Felix Gmuender, RBP Baster And Hoffmann ,“ Autoclave Validation For Microbiological And Biomedical Laboratories" Asia Pacific Biosafety Association, By Temasek Life Sciences, Singapore Jan 2010.(3) 